\title{
Lembar Kerja Siswa Berbasis ICT Sebagai Solusi Kegiatan Latihan Pembelajaran Mandiri
}

\author{
Kuntum An Nisa Imania \\ Pendidikan Teknologi Informasi STKIP Garut \\ Jl. Pahlawan no 32 Garut \\ kuntum_27eyahoo.com
}

Abstract - The main problem in this paper is focused on the use of ICT based on students' worksheet as a solution in learning activities. The achievement of students' learning outcomes is not easy to be solved the main problem (the root of the problem). One of which is to train students with exercises, then a collection of exercises is widely used by educators (teachers) in the form of print media or hard copy called LKS, but unfortunately sometimes the presence of LKS is generally only a set of questions that monotony which often lead to boredom, so that students become lazy in working the exercises. Sometimes the serving method of students' worksheet also monotonous and less varied. The student worksheet that contains questions of subjects may be categorized as subjects less desirable by the students such as, math, English or science. If the serving method of students' worksheet are not accompanied by variations, the students will get bored and unwilling to understand the questions.

With the presence of LKS based ICT can address all the needs of students and teachers in implementing the learning activities to be more variety, innovative and able to enhance students' creativity. In addition, in the terms of time it is more flexible, because of the presence of ICT-based worksheets students are able to do the exercises wherever they are, as long as they were able to connect with the Internet network and can access it.

The model of ICT based on interactive of the collection of exercises (LKS) is different from the collection of exercises (LKS) circulated in the schools. This LKS based on ICT interactive worksheets are used to deliver the material into a series of questions as an introduction to learners in constructing their understanding. The series of questions to each other are interconnected. So that students have to learn the use of these worksheets in a coherent from beginning to end of materials. The learners learn the material presented through questioning so that the formula or concept was found by the learners.

Keywords - ICT, Students' Worksheet, Learning, Learning Achievement

\section{Identifikasi Masalah}

\section{PENDAHULUAN}

Perolehan prestasi siswa dengan penerapan LKS berbasis media cetak yang selama ini digunakan juga tidak menjamin ketuntasan belajar. Berdasarkan perolehan nilai yang ada setelah menjawab pertanyaan dikumpulkan skor banyak yang tidak mencapai nilai 75 sebagai kriteria ketuntasan minimum. Hal tersebut dapat disebabkan oleh managemen waktu yang tidak efektif sehingga penggunaan LKS media cetak tidak selalu ikut dalam perencanaan pembelajaran. Borosnya waktu yang dipakai untuk pengerjaan LKS tersebut membatasi penguatan dari guru dan proses diskusi yang terlaksana di kelas sehingga LKS yang ada lebih cocok dikatakan sebagai lembar tugas saja.

Lembar Kerja Siswa atau Lembar Kegiatan Siswa yang mudahnya disingkat dan disebut dengan LKS merupakan salah satu bahan ajar yang dapat digunakan dan diterapkan dalam pembelajaran. Banyak sekali guru yang memilih untuk menggunakan LKS dalam pembelajaran yang akan dilakukan. LKS banyak dipilih. karena cukup mampu untuk menyajikan materi pelajaran yang hendak disampaikan dan disertai pula dengan latihan dan evaluasi yang cukup banyak. Lembar Kerja Siswa (LKS) merupakan salah satu alternatif pembelajaran yang tepat bagi peserta didik karena LKS membantu peserta didik untuk menambah informasi tentang konsep yang dipelajari melalui kegiatan belajar secara sistematis (suyitno, 1997:40). Namun biasanya lembar kerja siswa berisikan materi soal sehingga bagi siswa yang selalu menggunakan lembar kerja siswa akan merasa bosan. Dan cara penyajian Lembar kerja siswa juga terkadang terkesan monoton kurang bervariasi. Belum lagi lembar kerja siswa itu berisikan soal-soal mata pelajaran yang boleh dikategorikan mata pelajaran yang kurang diminati siswa seperti, matematika, bahasa inggris atau IPA Jika dalam penyajiannya lembar kerja siswa tidak dibarengi dengan variasi maka siswa akan cepat bosan dan enggan untuk memahami isi soal.

\section{Tinjauan Pustaka}

A. Media Pembelajaran

Menurut Heinich, Molenda, dan Russel mengemukakan bahwa Media is a channel of communication. Derived from the latin word for "between", the term refers "to anything that carries information between a source and receiver. ${ }^{1}$ Media salah satu alat komunikasi dalam memyampaikan pesan tentunya sangat bermanfaat jika diimplementasikan ke dalam proses pembelajaran, media yang digunakan dalam proses pembelajaran tersebut disebut sebagai media pembelajaran.

\footnotetext{
${ }^{1}$ Heinich, dkk, Media Third Edition (New York: Prentice
} Hall, 1990), h. 6. 
Media pembelajaran menurut Miarso $(2004)^{2}$ adalah segala sesuatu yang digunakan untuk menyalurkan pesan serta dapat merangsang pikiran, perasaaan, perhatian, dan kemauan si belajar sehingga dapat mendorong terjadinya proses belajar yang disengaja, bertujuan dan terkendali. Pemanfaatan media harus terencana dan sistemik sesuai dengan tujuan pembelajaran. Kehadiran media sangat membantu di dalam peserta didik untuk memahami sutau konsep tertentu yang sulit dijelaskan dengan bahasa verbal, dengan demikian pemenfaatan media sangat tergantung pada karakteristik media dan kemampuan pengajar maupun peserta didikmemahami cara kerja media tersebut, sehingga pada akhirnya media dapat dipergunakandan dikembangkan sesuai dengan tujuan pembelajaran yang diharapkan. Mengacu pada beberapa definisi media tersebut, penulis menarik kesimpulan bahwa media pembelajaran adalah semua bentuk perantara yang digunakan oleh guru/widiaswara/tutor,dsb untuk menyampaikan informasi, pendapat atau gagasan yang di sampaikan kepada peserta didik, sehingga merangsang pikiran, perasaan, perhatian, dan kemauan siswa untuk belajar dan mencapai sebuah tujuan pembelajaran.

\section{B. Multimedia Pembelajaran}

Kata multimedia bukanlah hal baru, tetapi sudah digunakan bahkan sebelum komputer dikembangkan, dan prioritas atau penyajian yang menggunakan beberapa macam cara ${ }^{3}$ (Anleigh \& Kiran, 1996) dalam buku Ariesto Hadi Sutopo. Pada awal tahun 1990, multimedia berarti kombinasi dari teks dengan dokumen image. Contoh lainnya, penggunaan slide $35 \mathrm{~mm}$ dengan rekaman audio merupakan bentuk multimedia. Sejalan dengan pendapat tersebut, Vaughan ${ }^{4}$ (2006) dalam Ariesto Hadi Sutopo mengatakan bahwa multimedia merupakan kombinasi antara teks, seni, suara, animasi, dan video yang disampaikan melalui komputer atau peralatan elektronik dan digital. Dengan demikian secara sederhana dapat diartikan multimedia pembelajaran dapat diartikan sebagai aplikasi multimedia yang digunakan dalam proses pembelajran, dengan kata lain untuk menyalurkan pesan (pengetahuan, keterampilan dan sikap) serta dapat merangsang piliran, perasaan, perhatian dan kemauan yang belajar sehingga secara sengaja proses belajar terjadi, bertujuan dan terkendali.

\section{Penggunaan Multimedia Pembelajaran}

Multimedia dapat digunakan untuk bermacammacam bidang pekerjaan, tergantung dari kreativitas untuk mengembangkannya. Aplikasi multimedia dibagi menjadi tiga kategori utama, yaitu presentasi bisnis,aplikasi pelatihan dan pembelajaran, serta game dan hiburan.

\footnotetext{
${ }^{2}$ Yusufhadi Miarso, Menyemai Benih Teknologi Pendidikan (Jakarta: Kencana,2005), hh. 457-458.

${ }^{3}$ Ariesto Hadi Sutopo, Teknologi Informasi dan Komunikasi dalam Pendidikan, (Jogyakarta: Graha Ilmu, 2012), h. 102.

${ }^{4}$ Ibid., h. 103.
}

(Anleigh \& Kiran, 1996) ${ }^{5}$ dalam Ariesto Hadi S. Menurut pandangan konstruksi pengetahuan, multimedia pembelajaran adalah aktivitas sense-making atau penalaran masuk akal, orang yang belajar berusaha membangun representasi mental yang koheren dari materi yang disajikan. Tidak seperti informasi, yakni komoditas objektif yang bisa dipindahkan dari satu otak ke otak lainnya, maka pengetahun selalu terkonstruksi secara personal oleh masing-masing orang dan tidak bisa dikirimkan dalam bentuk tertentu/pasti dari satu otak ke otak lain. Oleh karena inilah, maka kedua orang tidak bisa diberi pesan multimedia yang sama. Oleh karena ini pula, masing-masing orang bisa mendapatkan hasil pembelajaran yang berbeda. Kedua, menurut pandangan konstruksi pengetahuan, tugas murid adalah memahami materi yang disajikan. Oleh karena itu, murid adalah pihak aktiv yang mencari pemahaman, yang mengindera presentasi multimedia dan mencoba menata lalu memadukan materi-materi yang disajikan ke dalam representasi mental koheren. Ketiga, tugas guru adalah membantu murid dalam proses pemahaman/penalaran. Jadi, guru adalah pemandu kognitif yang memberikan bimbingan yang diperlukan untuk mendukung pemrosesan kognitif murid. Tanggungjawab ini ada di pihak murid, sedangkan guru hanya berperan sebagai fasilitator. Keempat, tujuan dari presentasi multimedia tidak hanya untuk menyajikan informasi tapi juga memberikan bimbingan bagaimana memproses informasi yang disajikan. Yakni menentukan apa yang harus diberi perhatian, bagaimana secara mental mengenalinya, dan bagaimana menghubungkannya dengan pengetahuan-pengetahuan terdahulu. Akhirnya metafora pembimbingnya adalah multimedia sebagai komunikator yang sangat membantu.

D. Metode Drill and Practice

Metode latihan (Driil) merupakan suatu cara mengajar yang baik untuk menanamkan kebiasaankebiasaan tertentu. Latihan adalah suatu teknik mengajar yang mendorong siswa untuk melaksanakan kegiatan latihan agar memiliki ketangkasan / keterampilan yang lebih tinggi dari apa yang dipelajari.

1) Fungsi dan manfaat metode Drill

Latihan siap atau drill sesuai untuk keterampilan, baik keterampilan fisik maupun keterampilan mental karena dengan latihan, sesuatu keterampilan dapat dikuasai. Beberapa hal yang yang harus diperhatikan dalam penggunaan teknik latihan.

2) Sifat latihan

Berbeda dengan latihan sebelumnya, karena situasi dan pengaruh latihan berbeda. Hal itu mendatangkan kondisi, respon serta tanggapan yang berbeda.

3) Penilaian Latihan

Dengan keseluruhan pelajaran disekolah perlu dikaitkan agar siswa ada dorongan motivasi untuk mengetahui tujuan latihan serta kaitannya dengan pelajaran sehingga dapat memanfaatkannya dalam kehidupan.

${ }^{5}$ Ibid., h. 120. 
Metode latihan (driil) ia berhubungan dengan pembentukan kemahiran motoris (fisik) ataukah kemahiran yang bersifat penyesuaian seperti kemahiran untuk memecahkan suatu soal atau kecakapan dalam penyelesaian diri terhadap suatu situasi (petunjuk pelaksanaan mengajar, 21: 22). Agar dapat mencapai tujuan yang diharapkan, guru harus memperhatikan dari pihak anak didik, yaitu mereka memiliki dorongan minat dan perhatian terhadap apa yang sedang dipelajari, pelaksanaan metoda latihan harus tetap diusahakan mengembangkan minat dan meningkatkan kemampuan anak didik.

E. Pembelajaran Berbasis ICT

Pada saat ini, pembelajaran ICT di lingkungan sekolah/universitas merupakan hal yang sangat penting. Hal ini dikarenakan semakin meningkatnya kebutuhan informasi dan komunikasi dalam berbagai keperluan seiring dengan perkembangan ilmu pengetahuan dan teknologi (IPTEK). ICT yang secara sederhana disimbolkan oleh perangkat computer dan jaringan internet serta perangkat komunikasi telah banyak dimanfaatkan untuk meningkatkan produktivitas kerja para pelajar mulai dari sekolah dasar hingga perguruan tinggi.

Satu bentuk produk TIK yang sedang menjadi "trend" adalah internet yang berkembang pesat di penghujung abad 20 dan di ambang abad 21. Kehadiran internet telah memberikan dampak yang cukup besar terhadap kehidupan umat manusia dalam berbagai aspek dan dimensi. Internet merupakan salah satu instrumen dalam era globalisasi yang telah menjadikan dunia ini menjadi transparan dan terhubungkan dengan sangat mudah dan cepat tanpa mengenal batas-batas kewilayahan atau kebangsaan.Melalui internet setiap orang dapat berkomunikasi. Bahkan, dunia pendidikan pun tidak luput untuk memanfaatkannya sehingga kelas maya dapat tercipta.

Hal yang paling mutakhir adalah berkembangnya apa yang disebut "cyber teaching" atau pengajaran maya, yaitu proses pengajaran yang dilakukan dengan menggunakan internet. Istilah lain yang makin populer saat ini ialah elearning yaitu satu model pembelajaran dengan menggunakan media TIK khususnya internet. Dengan elearning memungkinkan terjadinya proses belajar mengajar jarak jauh. E-learning merupakan dasar dari perkembangan teknologi informasi dan komunikasi. Dengan e-learning, peserta didik tidak perlu duduk dengan manis di ruang kelas untuk menyimak setiap ucapan dari seorang guru secara langsung.

F. LKS

Dalam dunia pendidikan, LKS adalah kumpulan hasil karya seorang siswa, sebagai hasil pelaksanaan tugas kinerja, yang ditentukan oleh guru atau oleh siswa bersama guru, sebagai bagian dari usaha mencapai tujuan belajar, atau mencapai kompetensi yang ditentukan dalam kurikulum. Jadi, tidak setiap kumpulan karya seorang siswa disebut LKS. LKS dapat digunakan sebagai instrumen penilaian atau salah satu komponen dari instrumen penilaian untuk menilai kompetensi belajar, atau menilai hasil belajar siswa.

\section{Hakikat LKS}

Pengetahuan tidak datang dan masuk ke dalam benak siswa seperti hujan turun dan meresap ke dalam tanah. Untuk memperoleh pengetahuan, siswa harus 'berjuang' dengan mencerna informasi yang datang dari guru, informasi dari media cetak (bahan tertulis), informasi yang terkandung di dalam benda-benda yang dijumpainya, dan sebagainya. Oleh karena itu, untuk memperoleh pengetahuan, siswa harus 'aktif', atau 'belajar secara aktif'. Oleh karena itu, dalam kelas yang ideal, siswa harus melakukan penyelidikan memecahkan masalah, mengeksplorasi gagasan-gagasan dengan menggunakan benda-benda konkret, menggunakan media pembelajaran, mengerjakan hal-hal tersebut secara mandiri dan secara berkelompok, atau dengan bekerja sama dalam kelompok kecil, mengungkapkan gagasan-gagasan, baik secara tertulis maupun secara lisan.

Agar siswa memahami materi pembelajaran, Partanto (1994: 44) mengajukan tujuh saran yang perlu di perhatikan sebagai berikut.

1) Berusaha memecahkan masalah nyata yang sesuai dengan perkembangan dan pengalamannya.

2) Bekerja baik mandiri maupun dalam kelompok.

3) Melakukan berbagai kegiatan seperti: menganalisis masalah, menjelaskan masalah, membuat dugaan atau terkaan tentang pemecahan masalah, menilai kebenaran pemecahan masalah, melakukan eksplorasi yang relevan dengan pembelajaran yang bersangkutan.

4) Menggunakan pengetahuannya dalam menghadapi masalah-masalah nyata.

5) Menggunakan berbagai alat bantu yang sesuai untuk meningkatkan pemahaman materi pembelajaran.

6) Mengkomunikasikan materi pembelajaran secara lisan dan tertulis.

7) Mempunyai sikap positif terhadap mata pembelajaran yang bersangkutan.

Prinsip itu memberikan kesempatan kepada siswa untuk melakukan eksplorasi tentang suatu perkara yang dipilihkan oleh guru. Siswa akan terlibat lebih aktif dalam pembelajaran. Jika siswa ikut memilih hal yang dieksplorasi, sesuai dengan minatnya atau gaya belajarnya. LKS merupakan alat bagi siswa untuk secara aktif memilih hal yang dieksplorasi, dan menunjukkan bukti tentang kompetensi siswa, di luar hasil tes. Dengan kata lain, di samping mengaktifkan siswa, Lembar Kerja Siswa (LKS) memberikan kesempatan kepada siswa untuk ikut serta dalam penilaian atas dirinya.

Tes yang lazim pada masa-masa lalu kebanyakan lebih menekankan pentingnya menilai pemahaman materi pembelajaran daripada pengetahuan siswa tentang kaidah, algoritma, prosedur, dan cara berpikir. Dalam hal pembelajaran yang menuntut penguasaan materi pembelajaran serta pemilikan keterampilan dan sikap yang baik, akan lebih baik jika digunakan instrumen penilaian yang memberikan kesempatan kepada siswa untuk 
menunjukkan kemampuannya dalam memecahkan masalah, bernalar, berkomunikasi, melakukan penyelidikan, dan berkreasi.

Untuk maksud tersebut, LKS merupakan salah satu instrumen yang cocok. Siswa SMP, SMA, dan SMK tentu berpendapat bahwa materi pembelajaran yang penting adalah materi yang diujikan atau yang sering muncul dalam tes. Dengan LKS, yang semua isinya akan dinilai. Siswa dapat diharapkan dapat memberikan perhatian yang tinggi pula kepada bagian-bagian yang tidak diujikan atau tidak masuk dalam tes. Jika guru ingin agar siswanya suka melakukan penyelidikan atau melakukan eksplorasi, tidak sekedar menghafal, dan siswanya tidak mudah melupakan materi tertentu, maka penggunaan (LKS) merupakan jalan yang cocok untuk maksud itu.

Fungsi LKS

Penggunaan LKS berfungsi sebagai berikut :

1) Menyajikan atau memberikan: bukti yang lebih jelas atau lebih lengkap tentang kinerja siswa daripada hasil tes di kelas.

2) Sebagai catatan penilaian yang sesuai dengan program pembelajaran yang baik.

3) Merupakan catatan jangka panjang tentang kemajuan siswa.

4) Memberikan gambaran tentang kemampuan siswa.

5) Memberikan kesempatan kepada siswa untuk menunjukkan keunggulan dirinya, bukan kekurangan atau kesalahannya dalam mengerjakan soal atau tugas.

6) Mencerminkan pengakuan atas bervariasinya gaya belajar siswa.

7) Memberikan kesempatan kepada siswa untuk berperan aktif dalam penilaian hasil belajar.

8) Membantu guru dalam menilai kemajuan siswa.

9) Membantu guru dalam mengambil keputusan tentang pembelajaran atau perbaikan pembelajaran.

10) Sebagai bahan yang relatif lengkap untuk berdiskusi dengan orang tua siswa, tentang perkembangan siswa yang bersangkutan.

11) Membantu pihak luar untuk menilai program pembelajaran yang bersangkutan.

Jadi, pada hakikatnya LKS itu adalah Sebagai bahan atau alat untuk membantu guru dan siswa dalam proses pembelajaran.

G. Prestasi Belajar

Prestasi belajar adalah sebuah kalimat yang terdiri dari dua kata, yakni prestasi dan belajar. Untuk memahami lebih jauh tentang pengertian prestasi belajar, peneliti menjabarkan makna dari kedua kata tersebut. Sedangkan menurut Saiful Bahri Djamarah (1994: 20-21) dalam bukunya Prestasi Belajar dan Kompetensi Guru, bahwa prestasi adalah apa yang telah dapat diciptakan, hasil pekerjaan, hasil yang menyenangkan hati yang diperoleh dengan jalan keuletan kerja. Dalam buku yang sama Nasrun harahap, berpendapat bahwa prestasi adalah penilaian pendidikan tentang perkembangan dan kemajuan siswa berkenaan dengan penguasaan bahan pelajaran yang disajikan kepada siswa.
Dari pengertian di atas dapat diambil kesimpulan bahwa prestasi adalah hasil dari suatu kegiatan seseorang atau kelompok yang telah dikerjakan, diciptakan dan menyenangkan hati yang diperoleh dengan jalan bekerja. Selanjutnya untuk memahami pengertian tentang belajar berikut dikemukakan beberapa pengertian belajar diantaranya menurut Slameto (2003: 2) dalam bukunya Belajar dan faktor-faktor yang mempengaruhinya bahwa belajar ialah suatu usaha yang dilakukan seseorang untuk memperoleh suatu perubahan tingkah laku yang baru secara keseluruhan, sebagai hasil pengalamannya sendiri dalam interaksi dengan lingkungannya. Muhibbin Syah (2000: 136) bahwa belajar adalah tahapan perubahan seluruh tingkah laku individu yang relative menetap sebagai hasil pengalaman dan interaksi dengan lingkungan yang melibatkan proses kognitif. Begitu juga menurut James Whitaker yang dikutip oleh Wasty Soemanto (1990: 98-99), belajar adalah proses dimana tingkah laku ditimbulkan atau diubhah melalui latihan dan pengalaman.

Berdasarkan beberapa pendapat di atas bahwa belajar merupakan kegiatan yang dilakukan secara sadar dan rutin pada seseorang sehingga akan mengalami perubahan secara individu baik pengetahuan, keterampilan, sikap dan tingkah laku yang dihasilkan dari proses latihan dan pengalaman individu itu sendiri dalam berinteraksi dengan lingkungannya.

Menurut Winkel melalui Sunarto (2006: 162) mengatakan bahwa "prestasi belajar adalah suatu bukti keberhasilan belajar atau kemampuan seorang siswa dalam melakukan kegiatan belajarnya sesuai dengan bobot yang dicapainya". Menurut Abu Ahmadi dan Widodo Supriyono (2010: 130) prestasi belajar merupakan hasil interaksi antara berbagai faktor yang mempengaruhinya baik dari dalam diri (faktor internal) maupun dari luar (faktor eksternal) individu. Berdasarkan beberapa batasan diatas, prestasi belajar dapat diartikan sebagai kecakapan nyata yang dapat diukur yang berupa pengetahuan, sikap dan keterampilan sebagai interaksi aktif antara subyek belajar dengan obyek belajar selama berlangsungnya proses belajar mengajar untuk mencapai hasil belajar.

Faktor - faktor yang Mempengaruhi Prestasi belajar

Adapun faktor-faktor yang mempengaruhi prestasi belajar secara umum menurut Slameto (2003: 54) pada garis besarnya meliputi faktor intern dan faktor ekstern yaitu:

1. Faktor Intern

Dalam faktor ini dibahas 2 faktor yaitu:

a) Faktor jasmaniah mencakup:

- Faktor kesehatan

- Cacat Tubuh

b) Faktor psikologis mencakup:

G. Intelegensi

H. Perhatian

I. Minat bakat

J. Motivasi

K. Kematangan

L. Persiapan

c) Faktor kelelahan 
2. Faktor ekstern

Faktor ini dibagi menjadi 3 faktor, yaitu:

a) Faktor keluarga mencakup:

- Cara orang tua mendidik

- Relasi antar anggota keluarga

- Suasana rumah

- Keadaan ekonomi keluarga

- Pengertian orang tua

- Latar belakang kebudayaan

b) Faktor sekolah meliputi :

Metode mengajar kurikulum, relasi guru dengan siswa, relasi siswa dengan siswa, disiplin sekolah, alat pelajaran, waktu sekolah, standar pelajaran di atas ukuran, keadaan gedung, metode belajar, dan tugas rumah.

c) Faktor masyarakat meliputi :

Kegiatan dalam masyarakat, mass media, teman bermain, bentuk kehidupan bermasyarakat.

\section{Tujuan Penelitian}

Tujuan dari penelitian adalah untuk mengetahui manfaat penggunaan LKS berbasis ICT kegiatan belajar siswa dalam mengerjakan latihan soal. Dengan adanya media tersebut diharapkan siswa lebih termotivasi lagi dalam mengerjakan latihan-latihan soal yang pada umumnya latihan soal berbentuk LKS membuat siswa jenuh karena jumlahnya yang begitu banyak serta bentuknya yang monoton. Penelitian ini diharapkan dapat menjadi inovasi dalam kawasan pengembangan teknologi pendidikan, khususnya mengenai pengembangan teknologi multimedia pembelajaran berbasis ICT untuk pembelajaran.

\section{Manfaat Penelitian}

Dengan adanya LKS berbasis ICT ini diharapkan guru untuk mengarahkan pembelajaran atau memperkenalkan suatu kegiatan tertentu. Dapat mempercepat proses belajar mengajar dan hemat waktu mengajar. Dapat mengoptimalkan alat bantu pengajaran yang terbatas karena siswa dapat menggunakan alat bantu secara bergantian. Dengan demikian beberapa manfaat dari LKS berbasis ICT berikut :

1. LKS berbasis TIK yang dibuat dapat menjadi alternatif belajar siswa selain media cetak.

2. LKS berbasis TIK yang dibuat dapat membangkitkan kreativitas guru Biologi khususnya dan guru bidang studi lain pada umumnya.

3. Bagi peneliti, meningkatkan semangat untuk menulis dan terus menggali pengetahuan serta keterampilan.

4. Bagi Sekolah sebagai salah satu upaya mengembangkan kreatifitas guru.

\section{PEMBAHASAN}

\section{A. Lembar Kerja Siswa (LKS)}

Lembar kerja siswa (LKS) adalah lembaran-lembaran yang digunakan sebagai pedoman di dalam pembelajaran serta berisi tugas yang harus dikerjakan oleh peserta didik dalam kajian teretentu. LKS sangat baik dipergunakan dalam rangka strategi heuristik maupun ekspositorik. Dalam strategi heuristik LKS dipakai dalam metode penemuan terbimbing, sedangkan dalam strategi ekspositorik LKS dipakai untuk memberikan latihan pengembangan. Selain itu LKS sebagai penunjang untuk meningkatkan aktifitas siswa dalam proses belajar dapat mengoptimalkan hasil belajar. Dari beberapa pengertian di atas dapat disimpulkan bahwa LKS adalah media cetak yang terdiri dari satu atau dua lembar atau lebih yang diberikan kepada setiap siswa disatu kelas dengan tujuan untuk melakukan aktivitas belajar mengajar.LKS harus disusun dengan tujuan dan prinsip yang jelas. Adapun tujuan meliputi:

1) Memberikan pengetahuan dan sikap serta ketrampilan yang perlu dimiliki siswa,

2) Mengecek tingkat pemahaman siswa terhadap materi yang telah disajikan,

3) Mengembangkan dan menerapkan materi pelajaran yang sulit dipelajari.

Sedang prinsipnya meliputi:

1) Tidak dinilai sebagai dasar perhitungan rapor, tetapi hanya diberi penguat bagi yang berhasil menyelesaikan tugasnya serta diberi bimbingan bagi siswa yang mengalami kesulitan.

2) Mengandung permasalahan

3) Sebagai alat pengajaran

4) Mengecek tingkat pemahaman

5) Pengembangan dan penerapannya

6) Semua permasalahan sudah dijawab dengan benar setelah selesai pembelajaran

Peran dan fungsi

Peran LKS sangat besar dalam proses pembelajaran karena dapat meningkatkan aktifitas siswa dalam belajar dan penggunaannya dalam pembelajaran dapat membantu guru untuk mengarahkan siswanya menemukan konsep-konsep melalui aktifitasnya sendiri. Disamping itu LKS juga dapat mengembangkan keterampilan proses, meningkatkan aktifitas siswa dan dapat mengoptimalkan hasil belajar.

Lembar kerja siswa mempunyai fungsi antara lain:

1) Untuk tujuan latihan

Siswa diberikan serangkaian tugas/aktivitas latihan. Lembar kerja seperti ini sering digunakan untuk memotivasi siswa ketika sedang melakukan tugas latihan.

2) Untuk menerangkan penerapan (aplikasi)

Siswa dibimbing untuk menuju suatu metode penyelesaian soal dengan kerangka

penyelesaian dari serangkaian soal-soal tertentu. Hal ini bermanfaat ketika kita

menerangkan penyelesaian soal aplikasi yang memerlukan banyak langkah. Lembaran

kerja ini dapat digunakan sebagai pilihan lain dari metode tanya jawab, dimana siswa

dapat memeriksa sendiri jawaban pertanyaan itu.

3) Untuk kegiatan penelitian

Siswa ditugaskan untuk mengumpulkan data tertentu, kemudian menganalisis data tersebut. Misalnya dalam penelitian statistika.

4) Untuk penemuan 
Dalam lembaran kerja ini siswa dibimbing untuk menyelidiki suatu keadaan tertentu, agar menemukan pola dari situasi itu dan kemudian menggunakan bentuk umum untuk membuat suatu perkiraan. Hasilnya dapat diperiksa dengan observasi dari contoh yang sederhana.

5) Untuk penelitian hal yang bersifat terbuka

Penggunaan lembaran kerja siswa ini mengikutsertakan sejumlah siswa dalam penelitian dalam suatu bidang tertentu. Secara umum, manfaat yang dapat diperoleh dari penggunaan LKS.

Prinsip-Prinsip Pembelajaran Menggunakan LKS

Teknologi pembelajaran dibangun atas dasar prinsipprinsip yang diambil dari teori psikologi, terutama teori belajar dan hasil-hasil penelitian dalam kegiatan pembelajaran. Suparman (1997:31) yang mengutip pendapat Filbeck mengelompokkan prinsip-prinsip yang digunakan dalam pembelajaran menjadi 12 macam.

1) Prinsip respon yang berakibat menyenangkan siswa. Implikasinya: (a) perlunya umpan balik positif dengan segera, (b) keharusan pembelajar untuk aktif membuat respons, dan (c) perlunya pemberian latihan (exercise) dan tes.

2) Prinsip kondisi atau tanda untuk menciptakan perilaku tertentu, implikasinya yakni: (a) perlunya kejelasan mengenai standar kompetensi maupun kompetensi dasar: (b) penggunaan variasi metode dan media.

3) Prinsip pemberian akibat yang menyenangkan implikasinya yakni: (a) pemberian isi/materi pokok yang berguna, (b) imbalan dan penghargaan terhadap keberhasilan pembelajar. (c) seringnya pemberian latihan dan tes.

4) Prinsip transfer pada situasi lain implikasinya yakni: (a) pemberian kegiatan belajar yang mirip dengan kondisi dunia nyata, (b) pemberian contoh-contoh riil/nyata, dan (c) penggunaan variasi metode dan media.

5) Prinsip generalisasi dan pembedaan sebagai dasar untuk belajar sesuatu yang komplek. Implikasinya adalah perlunya keseimbangan dalam memberikan contoh (baik-buruk, positif-negatif, ganjil-genap, konkrit-abstrak, dsb.).

6) Prinsip pengaruh status mental terhadap perhatian dan ketekunan Implikasi adalah perlunya menarik/memusatkan perhatian pembelajar.

7) Prinsip membagi kegiatan ke dalam langkah-langkah kecil implikasinya yakni: (a) penggunaan buku teks terprogram (programmed texts atau programmed instructions), (b) pemenggalan kegiatan menjadi kecilkecil, disertai latihan dan umpan balik.

8) Prinsip pemodelan bagi materi yang kompleks, Implikasinya adalah penggunaan metode dan media yang dapat menggambarkan model (simplifikasi) dari benda/kegiatan nyata.

9) Prinsip keterampilan tingkat tinggi terbentuk dari keterampilan-keterampilan dasar, Implikasinya adalah Standar kompetensi maupun kompetensi dasar hendaknya dirumuskan seoperasional mungkin dan diturunkan/dijabarkan melalui analisis instruksional.

10) Prinsip pemberian informasi tentang perkembangan kemampuan pembelajar. Implikasinya: (a) urutan pembelajaran dimulai dari yang sederhana bertahap menuju ke yang makin komplek (the widening horizons or expanding community). (b) kemajuan harus diinformasikan.

11) Prinsip variasi dalam kecepatan belajar Implikasi: (a) pentingnya penguasaan materi prasyarat, (b) kesempatan untuk maju menurut kecepatan masingmasing.

12) Prinsip persiapan/kesiapan, implikasinya adalah pemberian kebebasan kepada pembelajar untuk memilih waktu, cara dan sumber belajar lain.

\section{B. Lembar Kerja Siswa Berbasis ICT}

Lembar kerja siswa (LKS) pada penelitian ini mempunyai pengertian lembar kerja bagi para peserta didik yang disajikan dalam bentuk pertanyaan yang dapat mengkonstruk pemahaman peserta didik tanpa harus didampingi oleh guru. Dalam penggunaan LKS ini berbasis Web sebagai media penyampaiannya kepada peserta didik, Web digunakan karena mempunyai jaringan luas dan akan memberikan

kesempatan lebih luas kepada peserta didik untuk memilih waktu, tempat maupun materi yang akan dipelajari. LKS interaktif ini memiliki karakteristik sendiri dan berbeda dengan LKS yang beredar di sekolah saat ini. Adapun perbedaan LKS konvensional dan LKS berbasis ICT terlihat pada table berikut

\section{Tabel I}

\begin{tabular}{|l|l|}
\hline No & Perbedaan LKS Konvensional LKS berbasis ICT \\
\hline 1 & $\begin{array}{l}\text { Materi Bentuk deskriptif Disajikan dalam bentuk } \\
\text { pertanyaan yang dapat mengkonstruk pemahaman } \\
\text { peserta didik }\end{array}$ \\
\hline 2 & $\begin{array}{l}\text { Gambar, grafik maupun tulisan Dalam keadaan diam } \\
\text { Disajikan bergerak dan langkah per langkah, ketika } \\
\text { peserta didik tidak mengerti dapat diulang }\end{array}$ \\
\hline 3 & $\begin{array}{l}\text { komunikasi Dilakukan dengan satu arah Dua arah } \\
\text { ketika peserta didik memberikan jawaban atau } \\
\text { respon LKS ini akan memberikan respon/umpan } \\
\text { balik) }\end{array}$ \\
\hline 4 & $\begin{array}{l}\text { Isi Menekankan banyak pada soal-soal. Menekankan } \\
\text { pada penanaman konsep, soal hanya dijadikan } \\
\text { sebagai pengantar pemahaman peserta didik }\end{array}$ \\
\hline 5 & $\begin{array}{l}\text { Tampilan Disajikan pada lembaran kertas. Disajikan } \\
\text { lebih menarik dengan tampilan gambar yang disukai } \\
\text { oleh anak-anak dan tampilannya lebih hidup. }\end{array}$ \\
\hline
\end{tabular}

Dari tabel tersebut terlihat jelas perbedaan antar kedua LKS. Berdasarkan tabel tersebut pula dapat diprediksi bahwa LKS interaktif ini akan mampu diterima di dunia pendidikan sebagai sebuah pelengkap dalam proses 
pembelajaran. Kemajuan teknologi komputer dan internet turut mendukung perkembangan model pembelajaran. Penggunaan komputer tidak terbatas dan memiliki potensi yang besar sebagai media dalam pembelajaran. Penggunaan LKS interaktif berbasis ICT ini akan mampu membantu peserta didik dalam mencapai tujuan dari kurikulum. Peserta didik dapat mengatur kecepatan belajarnya, disesuaikan dengan tingkat kemampuannya. Mereka dapat mengulang beberapa kali sehingga benar-benar menguasai materi yang harus dipahaminya. LKS ini juga dapat diperbaharui sewaktu-waktu jika memang dipandang masih ada kekurangan dan tidak relevan dengan perkembangan jaman. Penggunan ICT sebagai media penyampaian LKS dimaksudkan agar peserta didik dapat memilih waktu dan tempat untuk belajar.

\section{Berbasis ICT}

Kelebihan dan Kekurangan Lembar Kerja Siswa Lembar kerja Siswa (LKS) interktif berbasis ICT memiliki kelebihan dan kekurangan. Kelebihan LKS berbasis ICT dibanding dengan model LKS yang lain adalah sebagai berikut ini.

\section{Kelebihan LKS berbasis ICT}

a. Peserta didik diajak untuk menemukan rumus dan konsep dengan pengetahuan dan pemahaman yang dimiliki sebelumnya melalui serangkaian pertanyaan yang membangun. Hal ini menjadikan pemahaman dan penguasaan materi akan lebih lama dalam ingatan karena peserta didik yang menemukan rumus maupun konsep itu sendiri.

b. LKS interaktif bebasis ICT ini mampu untuk menampilkan gambar-gambar yang abstrak (sulit dibayangkan) semisal bangun ruang, grafik dan sebagainya. Gambar maupun grafik ini dapat ditampilkan dengan bentuk dan animasi yang lebih nyata dan menarik sehingga peserta didik akan belajar dengan suasana senang. Hal ini akan menjadikan materi yang disampaikan akan secara cepat dipahami peserta didik.

2. Kekurangan LKS berbasis ICT

a. Pembuatan LKS berbasis ICT membutuhkan waktu yang lama dan biaya yang tidak sedikit. Namun kendala ini dapat diatasi dengan adanya kerja sama yang baik antara semua pihak yang terkait.

b. Kemampuan peserta didik dalam menjalankan komputer maupun internet masih kurang. Namun hal ini masih bisa diselesaikan dengan adanya latihan dan mata pelajaran teknologi infomasi di sekolah, serta LKS ini juga dilengkapi dengan petunjuk cara penggunaanya.

Konsep Model LKS Interaktif dan ICT

Model LKS interaktif berbasis ICT berbeda dengan

LKS yang beredar di sekolah-sekolah. LKS interaktif berbasis ICT ini digunakan untuk menyampaikan materi dengan serangkaian pertanyaan-pertanyaan sebagai pengantar peserta didik dalam mengkonstruk pemahamannya. Serangkaian pertanyaan tersebut satu dengan yang lain saling terkait. Sehingga peserta didik harus belajar menggunakan LKS ini secara runtut dari awal sampai akhir. Peserta didik mempelajari materi yang disajikan melalui pertanyaan sehingga rumus atau konsep itu ditemukan sendiri oleh peserta didik.

\section{Deskripsi Produk Lembar Kerja Siswa Berbasis ICT}

Lembar kerja siswa (LKS) merupakan salah satu bahan ajar yang digunakan dalam pembelajaran yang berisi materi, ringkasan, petunjuk pelaksaanaan tugas yang harus dikerjakan siswa. LKS berfungsi untuk meminimalkan peran pendidik, mempermudah peserta didik untuk memahami materi yang diberikan, sebagai bahan ajar yang ringkas dan kaya tugas untuk berlatih, dan mempermudah pelaksanaan pembelajaran kepada peserta didik. LKS yang dibuat memiliki beberapa keunggulan yaitu dapat digunakan dimana saja dan kapan saja.

LKS dibuat sesuai dengan struktur yang telah disusun. Struktur LKS meliputi: Home, pendahuluan, kompetensi, lembar kerja siswa, evaluasi dan unduh. Materi yang ada pada LKS ini meliputi materi pembelajaran di digunakan di sekolah. LKS dibuat menggunakan CMS dengan software Joomla 1.5. Semua halaman pada LKS ini dibuat menggunakan Microsoft word, dan Microsoft power point.

Halaman utama memberikan gambaran umum pada pengguna tentang topik-topik yang ada pada LKS. Pada halaman utama pengguna dapat mengetahui menu utama pada LKS. Menu utama LKS meliputi: home, pendahuluan, kompetensi, lembar kerja siswa, evaluasi, dan unduh. Pada halaman utama terdapat kalender, jam dan penghitung pengunjung.

Bagian pertama yang bisa diakses oleh pengguna pada menu utama adalah menu pendahuluan. Pendahuluan adalah menu yang menampilkan pengenalan LKS secara singkat dan petunjuk penggunaan LKS.

Bagian kedua yang bisa diakses pengguna adalah menu kompetensi. Kompetensi berisikan SK, KD dan indikator yang akan dicapai dalam kegiatan pembelajaran. LKS 1-4 berisikan SK, KD dan indikator, sedangkan LKS 5-6 berisikan SK, KD dan Indikator.

Bagian ketiga dan keempat adalah alokasi waktu dan informasi singkat. Alokasi waktu berguna untuk memberi informasi waktu yang digunakan dalam menggunakan LKS berbasis ICT ini. Informasi singkat berisi ringkasan materi yang dipelajari dalam kegiatan pembelajaran. Materi dilengkapi dengan nilai-nilai karakter.

Bagian kelima dari LKS ini adalah sumber belajar. Sumber belajar cetak yang diambil dari buku dan sumber belajar non cetak yang diambil dari internet. Pada sumber belajar cetak dicantumkan nama pengarang, tahun terbit, judul buku, penerbit dan tempat diterbitkan. Untuk sumber belajar non cetak dicantumkan alamat websitenya.

Bagian keenam terdapat prosedur kerja. Prosedur kerja berisi langkah-langkah kerja yang dilakukan selama kegiatan pembelajaran. Pada bagian prosedur kerja ini 
terdapat nilai-nilai karakter yang ditanamkan pada diri siswa.

Bagian terakhir dari LKS ini adalah tugas. Menu yang keempat adalah evaluasi. Evaluasi dibuat dengan menggunakan aplikasi quiz creator kemudian dilinkkan pada tulisan ataupun tulisan yang terdapat pada kotak.

Evaluasi dirancang agar siswa mengerjakan latihan secara mandiri untuk mengetahui tingkat pemahaman terhadap materi yang telah dipelajari. Disamping itu, evaluasi juga dapat melatih kejujuran siswa dalam mejawab soal yang diberikan.

Menu terakhir yang dapat diakses adalah bagian menu unduh. merupakan link yang memungkinkan siswa dapat mengunduh semua topik ada pada LKS ini.

\section{Kriteria Lembar Kerja Siswa}

Untuk menghasilkan LKS yang baik, perlu diketahui kriteria LKS yang baik. LKS haruslah memenuhi persyaratan tertentu. Beberapa hal yang perlu dipertimbangkan dalam menyusun LKS menurut Juariah (1999 dalam Anggaryani, 2006:9) adalah sebagai berikut:

1) Mengacu pada kurikulum.

2) Bahan mudah dicerna.

3) Mendorong siswa untuk belajar atau bekerja.

4) Ada kesesuaian antara materi dan waktu yang tersedia.

5) Digunakan untuk melaksanakan kegiatan atau pemecahan masalah dan menarik kesimpulan.

6) Digunakan untuk menemukan konsep

Adapun persyaratan yang harus dipenuhi dalam membuat LKS menurut Anggaryani (2006:10) adalah sebagai berikut :

a. Syarat-syarat didaktik

LKS sebagai salah satu bentuk sarana berlangsungnya proses pembelajaran harus mengikuti asasasas pembelajaran yang efektif, yaitu:

1) Tekanan pada proses untuk menemukan konsepkonsep sehingga LKS di sini berfungsi sebagai petunjuk bagi siswa untuk mencari tahu.

2) Memperhatikan adanya perbedaan individual, sehingga LKS yang baik itu dapat digunakan untuk mengukur kemampuan siswa.

b. Syarat-syarat konstruksi

Persyaratan konstruksi yang harus dipenuhi oleh LKS adalah syarat-syarat yang berkenaan dengan penggunaan bahasa, susunan kalimat, kesederhanaan pemakaian kata-kata dan kejelasan. LKS tepat guna dan dapat dimengerti siswa. Berkaitan dengan hal tersebut, ada beberapa hal yang harus diperhatikan dalam membuat LKS, seperti:

1) menggunakan bahasa yang sesuai dengan tingkat kedewasaan siswa.

2) Menggunakan struktur kalimat atau kata-kata yang jelas.

3) Memiliki tata urutan pelajaran yang sesuai dengan tingkat kemampuan siswa. Apabila konsep yang hendak dituju merupakan sesuatu yang kompleks, dapat dipecahkan menjadi bagian-bagian yang lebih sederhana.

4) Menggunakan kalimat yang sederhana dan pendek.

5) Memiliki tujuan belajar yang jelas serta pelajaran itu bermanfaat sehingga bisa menjadi sumber motivasi bagi siswa.

6) Mempunyai identitas untuk lebih memudahkan administrasi. Misalnya kelas, mata pelajaran, topik, tanggal dan sebagainya.

c. Syarat-Syarat Teknis

Penyusunan dan pembuatan LKS juga harus memenuhi syarat-syarat teknis sebagai berikut :

1) Tulisan

a) Menggunakan huruf cetak dan tidak menggunakan huruf romawi/latin.

b) Menggunakan huruf tebal yang agak besar untuk topik, bukan huruf biasa yang diberi garis bawah.

c) Jumlah kata dalam satu baris tidak lebih dari 10 kata.

2) Penampilan, harus memiliki kombinasi.

d. Langkah -langkah penulisan LKS sebagai berikut :

1) Melakukan analisis kurikulum: $\mathrm{SK}, \mathrm{KD}$, indikator dan materi pembelajaran.

2) Menyusun peta kebutuhan LKS.

3) Menentukan judul LKS.

4) Menulis LKS.

5) Menentukan alat penilaian.

e. Struktur LKS secara umum :

1) Judul, mata pelajaran, semester, tempat

2) Petunjuk belajar

3) Kompetensi yang akan dicapai

4) Indikator

5) Informasi pendukung

6) Tugas-tugas dan langkah-langkah kerja

7) Penilaian

f. Berdasarkan kriteria LKS peneliti susun kali ini adalah sebagai berikut:

1) Syarat-syarat didaktik, meliputi :

a) Materi sesuai dengan KTSP.

b) Memperhatikan adanya perbedaan individual, karena dalam KTSP menekankan pada adanya kompetensi maka LKS harus dapat mengukur kemampuan siswa.

c) Kegiatan mendukung pemahaman konsep, kegiatan dalam LKS membantu memahami konsep-konsep yang dipelajari.

d) Kegiatan dikaitkan dengan kehidupan nyata siswa dan teknologi, karena dalam kurikulum 2006 kegiatan pembelajaran lebih diarahkan pada pengalaman belajar ada baiknya bila kegiatan dikaitkan dengan kehidupan nyata dan teknologi seperti kegiatan menemukan.

2) Syarat-syarat konstruksi, meliputi:

a) Memiliki tujuan belajar yang jelas.

b) Memuat pokok-pokok materi dan rinciannya.

c) Menggunakan kalimat yang sederhana, jelas dan mudah dipahami. 
d) Memiliki tata urutan yang sesuai dengan tingkat kemampuan siswa.

e) Memiliki petunjuk untuk siswa mengenai topik yang dibahas,

f) pengarahan umum (prosedur kegiatan).

g) Mempunyai identitas, yang meliputi: (1) No.Materi Bab/Sub.Bab, (2) Judul, (3) Identitas siswa atau kelompok dan (4) Tanggal/Nilai/ Paraf guru.

h) Mendorong siswa belajar/bekerja secara ilmiah 3) Syarat - syarat teknis meliputi :

a) Tulisan, menggunakan huruf yang sesuai.

b) Penampilan, dari segi penampilan LKS harus dibuat menarik, perlu memperhatikan kebenaran isi, format dan susunan kata dalam LKS. Daftar pustaka tidak dicantumkan karena LKS ini merupakan hasil kreasi sendiri. Kunci LKS tidak perlu diberikan, karena LKS ini untuk siswa maka kunci tidak perlu diberikan.

Lembar kerja siswa yang dikembangkan harus memenuhi tiga kriteria utama yaitu; valid, praktis dan efektif. Menurut (Trianto, 2010:255) "valid artinya penilaian sudah memberikan informasi yang akurat tentang media yang dikembangkan". Praktis berarti mudah digunakan, menurut Lasmana (2011:84) praktikalitas berdasarkan respon guru dan siswa terhadap LKS yang memiliki nilai interpretasi yang baik sehingga mudah dipahami. Nilai efektif sangat penting untuk meningkatkan aktivitas, minat dan hasil belajar siswa (Lasmana,2011:88).

Lembaran kerja siswa itu berisikan petunjuk untuk melakukan kegiatan dan juga berisikan pertanyaan yang harus dijawab oleh siswa. Dengan diberikannya LKS dalam proses pembelajaran maka pengajaran yang diberikan lebih terarah dan menghindarkan siswa dari kegiatan yang tidak berguna untuk mencapai tujuan yang diinginkan dan waktu yang lebih efektif. Penyajian proses pembelajaran seperti ini dapat mengaktifkan siswa dalam belajar mengolah perolehannya (Said, 1997:51-52).

\section{Kesimpulan}

Perolehan prestasi siswa dengan penerapan LKS berbasis media cetak yang selama ini digunakan juga tidak menjamin ketuntasan belajar. Berdasarkan perolehan nilai yang ada setelah menjawab pertanyaan dikumpulkan skor banyak yang tidak mencapai nilai 75 sebagai kriteria ketuntasan minimum. Hal tersebut dapat disebabkan oleh managemen waktu yang tidak efektif sehingga penggunaan LKS media cetak tidak selalu ikut dalam perencanaan pembelajaran. Borosnya waktu yang dipakai untuk pengerjaan LKS tersebut membatasi penguatan dari guru dan proses diskusi yang terlaksana di kelas sehingga LKS yang ada lebih cocok dikatakan sebagai lembar tugas saja. LKS banyak dipilih. karena cukup mampu untuk menyajikan materi pelajaran yang hendak disampaikan dan disertai pula dengan latihan dan evaluasi yang cukup banyak. Lembar Kerja Siswa (LKS) merupakan salah satu alternatif pembelajaran yang tepat bagi peserta didik karena LKS membantu peserta didik untuk menambah informasi tentang konsep yang dipelajari melalui kegiatan belajar secara sistematis. Namun biasanya lembar kerja siswa berisikan materi soal sehingga bagi siswa yang selalu menggunakan lembar kerja siswa akan merasa bosan. Dan cara penyajian Lembar kerja siswa juga terkadang terkesan monoton kurang bervariasi. Belum lagi lembar kerja siswa itu berisikan soal-soal mata pelajaran yang boleh dikategorikan mata pelajaran yang kurang diminati siswa seperti, matematika, bahasa inggris atau IPA Jika dalam penyajiannya lembar kerja siswa tidak dibarengi dengan variasi maka siswa akan cepat bosan dan enggan untuk memahami isi soal.

Dengan hadirnya LKS berbasis ICT ini dapat menjawab segala kebutuhan siswa dan guru dalam melaksanakan kegiatan pembelajaran yang lebih variatif, inovatif dan mampu meningkatkan kreativitas siswa. Selain itu juga dari segi waktu yang mampu lebih fleksibel, karena dengan hadirnya LKS berbasis ICT ini siswa mampu mengerjakan latihan-latihan soal dimanapun mereka berada, selama mereka mampu terhubungan dengan jaringan internet dan dapat mengaksesnya.

Model LKS interaktif berbasis ICT berbeda dengan LKS yang beredar di sekolah-sekolah. LKS interaktif berbasis ICT ini digunakan untuk menyampaikan materi dengan serangkaian pertanyaan-pertanyaan sebagai pengantar peserta didik dalam mengkonstruk pemahamannya. Serangkaian pertanyaan tersebut satu dengan yang lain saling terkait. Sehingga peserta didik harus belajar menggunakan LKS ini secara runtut dari awal sampai akhir. Peserta didik mempelajari materi yang disajikan melalui pertanyaan sehingga rumus atau konsep itu ditemukan sendiri oleh peserta didik.

LKS merupakan lembaran-lembaran berisi tugas yang harus dikerjakan siswa. LKS berbasis ICT dengan mengintegrasikan nilai pendidikan karakter dibuat sesuai dengan desain yang telah disusun yakni home, pendahuluan, kompetensi, lembar kerja siswa, evaluasi, dan unduh.

Penggunaan LKS berbasis ICT dengan mengintegrasikan nilai pendidikan karakter menurut standar proses adalah praktis yang ditandai dengan nilai rata-rata oleh guru sebagai praktisi memiliki point yang cukup tinggi. LKS tugas yang telah dikerjakan oleh siswa tidak dapat disimpan. Tugas yang telah dikerjakan siswa dapat tersimpan dalam dalam data base.

Berdasarkan hasil yang dicapai dan keterbatasan dalam penelitian, maka dapat dikemukan beberapa saran. Pertama, guru atau peneliti selanjutnya dapat mengembangkan materi pada LKS untuk seluruh materi pelajaran.

Kedua, LKS ini bisa meningkatkan motivasi dan pemahaman siswa dalam mempelajari materi interaktif dan mengembangkan nilai karakternya. 
Ketiga, LKS ini dapat digunakan untuk pembelajaran yang menyenangkan, interaktif dan mengembang nilai karakter siswa di sekolah.

Keempat, LKS berbasis ICT dengan mengintegrasikan nilai pendidikan karakter yang telah dihasilkan dapat dikembangkan dalam bentuk pembelajaran e-learning.

Kelima, LKS ini bisa digunakan di labor komputer, siswa juga bisa membawa laptop untuk mendapatkan hasil yang maksimal dalam proses pembelajaran.

Keenam, LKS ini juga bisa dijadikan sebagai salah satu bahan ajar oleh guru dan sumber belajar oleh siswa.

\section{DAFTAR PUSTAKA}

[1] Ariesto Hadi Sutopo, Teknologi Informasi dan Komunikasi dalam Pendidikan, Jogyakarta: Graha Ilmu, 2012. h. 102.

[2] Carin, A.A., Teaching Modern Science. Six Edition. New York: Macmillan Publishing Company, 1993.

[3] Darma, dkk, Manajemen Prestasi Belajar, Jakarta: Rajawali Press, 2007.

[4] Heinich, dkk, Media Third Edition, New York: Prentice Hall, 1990. h. 6 .

[5] Nasrulloh, Otonomi Pendidikan dari Sentralisasi Menuju Desentralisasi, Jakarta: Rajawali Press, 2007.

[6] Prastowo, A., Panduan Kreatif Membuat Bahan Ajar Inovatif Menciptakan Metode Pembelajaran yang Menarik dan Menyenangkan, Jogjakarta: Diva Press, 2011.

[7] Priyanto, Pengembangan Multimedia Pembelajaran Berbasis Komputer, Jakarta: INSANIA, 2009.

[8] Saud, S. U, Inovasi Pendidikan, Bandung: Alfabeta, 2008.

[9] Supriyono, Strategi Pembelajaran, Malang : Universitas Negeri Malang, 2003.

[10] Suyitno, Amien, Dasar-dasar Proses Pembelajaran Matematika I, Semarang, Jurusan Pendidikan Matematika F Mipa Unnes, 2007. h. 40

[11] Trianto, Model Pembelajaran Terpadu. Jakarta: Bumi Aksara, 2011.

[12] Vaughan, Tay, Multimedia: Making It Work. 8th Edition, New York : McGraw-Hill, 2011.

[13] Yusufhadi Miarso, Menyemai Benih Teknologi Pendidikan, Jakarta: Kencana,2005, hh. 457-458. 